\title{
Libya and the United States
}


This page intentionally left blank 


\title{
Libya and the United States
}

Two Centuries of Strife

\author{
Ronald Bruce St John
}

\section{$\overline{\text { PENN }}$}

University of Pennsylvania Press

Philadelphia 
Copyright (C) 2002 University of Pennsylvania Press

All rights reserved

Printed in the United States of America on acid-free paper

$\begin{array}{llllllllll}10 & 9 & 8 & 7 & 6 & 5 & 4 & 3 & 2 & 1\end{array}$

Published by

University of Pennsylvania Press

Philadelphia, Pennsylvania 19104-4011

Library of Congress Cataloging-in-Publication Data

St John, Ronald Bruce.

Libya and the United States : two centuries of strife / Ronald Bruce St John.

p. $\quad \mathrm{cm}$.

Includes bibliographical references (p. ) and index.

ISBN 0-8122-3672-6 (cloth : alk. paper)

1. United States-Foreign relations-Libya. 2. Libya-Foreign relations-United States. I. Title

E183.8.L75S7 2002

$327.730612^{\prime} 09-\mathrm{dc} 21$

2002018049 
To Carol 
This page intentionally left blank 